Mollasalehi S., Rathnayake A., Aboumoemen A., Underwood J., Fleming A., Kulatunga U., and Coates P. (2017). "How BIM-Lean Integration Enhances the Information Management Process in the Construction Design.” In: LC3 2017 Volume II - Proceedings of the 25th Annual Conference of the International Group for Lean Construction (IGLC), Walsh, K., Sacks, R., Brilakis, I. (eds.), Heraklion, Greece, pp. 531-538. DOI: https://doi.org/10.24928/2017/0130

\title{
HOW BIM-LEAN INTEGRATION ENHANCES THE INFORMATION MANAGEMENT PROCESS IN THE CONSTRUCTION DESIGN
}

\author{
Sajedeh Mollasalehi ${ }^{1}$, Anushka Rathnayake ${ }^{2}$, Ahmed Adel Aboumoemen ${ }^{3}$, Jason \\ Underwood $^{4}$, Andrew Fleming ${ }^{5}$, Udayangani Kulatunga ${ }^{6}$, and Paul Coates ${ }^{7}$
}

\begin{abstract}
The construction industry faces significant challenges due to insufficient processes. Design phase is a key process of construction project lifecycle in which many problems and challenges occur. Most of the issues within the design process are mainly due to poor information management process. Therefore, it is important to adopt new innovative technologies and processes to improve information management. Over the last decade, the number of projects implementing innovative and technological processes such as BIM and Lean has been increased. However, rather applying BIM and Lean independently, integration of BIM features with lean principles would bring more benefits to the design process in terms of improving information management.

This paper studies the potential benefits of integrating BIM and Lean to improve information management in terms of reducing construction design problems associated with information management challenges.
\end{abstract}

Keywords: Lean construction, Building Information Modelling (BIM), Information management (IM).

\section{INTRODUCTION}

It is widely believed that many construction problems can be traced back to the design process due to many decision making processes and major amount of information exchange in the design process. The design process as the key process of any construction projects (Edmunds and Morris 2000) has significant impacts on both overall performance and efficiency of the project and on projects' time and cost (Formoso et al. 1998; Freire and Alarcón 2002). The success of overall quality and performance of the entire project lifecycle depends highly on the design process performance (Formoso et al 1998).

1 PhD Candidate, School of the Built Environment, University of Salford, UK, s.mollasalehi1@edu.salford.ac.uk

2 PhD Candidate, School of the Built Environment, University of Salford, UK, prasadini88salford@gmail.com

3 PhD Candidate, School of the Built Environment, University of Salford, UK, a.a.aboumoemen@edu.salford.ac.uk

4 Professor, School of the Built Environment, University of Salford, UK, j.underwood@salford.ac.uk

5 Senior Lecturer, School of the Built Environment, University of Salford, UK, a.j.fleming@salford.ac.uk

6 Senior Lecturer, School of the Built Environment, University of Salford, UK, u.kulatunga@salford.ac.uk

7 Fellow Higher Education Academy, School of the Built Environment, University of Salford, UK, s.p.coates@salford.ac.uk 
Furthermore, it was reported by the BEDC that "the majority of construction problems are related to poor design management" (1987, cited in Austin Baldwin and Newton 1994). Also, another major problem faced by the construction industry is interdisciplinary management of design information. Similarly, it was stated that more than $50 \%$ of the construction problems, specifically on construction site, were related to poor design information management (NEDC 1987, Cited in Baldwin et al 2010). Therefore, effective design management is critically important to overcome construction problems that are associated with the design process due to poor design information management.

\section{CURRENT STATE OF THE DESIGN PROCESS}

Effective design management consists of various processes and strategies that aim to solve major construction problems that arise during the design process. As mentioned above many construction problems occur during the design process (Formoso et al. 1998; Austin Baldwin and Newton 1994). These problems including Lack of communication and coordination, insufficient documentation, unbalanced sharing of resources, poor or missing input information, unreliable decision making, and design changes have been described briefly in the following table (table 1). All mentioned problems would consequently result in generating waste, such as rework, waiting and over processing, in the design process and later on construction site (Ningappa, 2011).

Table 1- Construction Design Problems

\begin{tabular}{|c|c|c|}
\hline Construction design problems & Description & Possible wastes \\
\hline $\begin{array}{l}\text { a) Lack of communication and } \\
\text { coordination }\end{array}$ & $\begin{array}{l}\text { Poor communication and coordination is a result of isolated } \\
\text { environment where the project team do not communicate } \\
\text { with each other to share information and knowledge. (Austin, } \\
\text { Baldwin, \& Newton, 1994). }\end{array}$ & $\begin{array}{l}\text { Defects and } \\
\text { Rework } \\
\text { Waiting } \\
\text { Over processing }\end{array}$ \\
\hline b) Insufficient documentation & $\begin{array}{l}\text { Producing inadequate documentations such as unclear } \\
\text { drawings with errors or inadequate details and missing } \\
\text { information on drawings or other projects documents. } \\
\text { (Austin, Baldwin, \& Newton, 1994). }\end{array}$ & $\begin{array}{l}\text { Defects and } \\
\text { Rework } \\
\text { Waiting } \\
\text { Over processing }\end{array}$ \\
\hline c) Unbalanced sharing of resources & $\begin{array}{l}\text { Sharing too many unnecessary information or lack of } \\
\text { information. (Austin, Baldwin, \& Newton, 1994). }\end{array}$ & $\begin{array}{l}\text { Defects and Rework } \\
\text { Waiting } \\
\text { Over processing } \\
\text { Unnecessary } \\
\text { movement } \\
\text { Over production }\end{array}$ \\
\hline d) Poor or missing input information & $\begin{array}{l}\text { Lack of sufficient information exchange is a result of poor } \\
\text { information management. This will result in missing } \\
\text { relevant information, excessive amount of information, } \\
\text { duplication of information. (Austin, Baldwin, \& Newton, } \\
\text { 1994). }\end{array}$ & $\begin{array}{l}\text { Defects and } \\
\text { Rework } \\
\text { Waiting } \\
\text { Over processing } \\
\text { Over production }\end{array}$ \\
\hline e) Unreliable decision making & $\begin{array}{l}\text { As decision making is a selection of the best solution from } \\
\text { possible alternatives, unreliable decision making will lead to } \\
\text { problem generating rather than problem solving. (Austin, } \\
\text { Baldwin, \& Newton, 1994). }\end{array}$ & $\begin{array}{l}\text { Defects and } \\
\text { Rework } \\
\text { Waiting } \\
\text { Over processing } \\
\text { Over production }\end{array}$ \\
\hline f) Design changes & $\begin{array}{l}\text { Design changes may involve changes in any activity, } \\
\text { information, order, task and any design related process which } \\
\text { would have negative impacts on the overall design phase. } \\
\text { (Austin, Baldwin, \& Newton, 1994). }\end{array}$ & $\begin{array}{l}\text { Defects and Rework } \\
\text { Waiting } \\
\text { Over processing } \\
\text { Unnecessary } \\
\text { movement } \\
\text { Over production }\end{array}$ \\
\hline
\end{tabular}


Sajedeh Mollasalehi, Anushka Rathnayake, Ahmed Adel Aboumoemen, Jason Underwood, Andrew Fleming, Udayangani Kulatunga and Paul Coates

\section{INFORMATION MANAGEMENT}

\subsection{Information Management}

According to Detlor (2010) Information Management (IM) is a procedure of managing "the processes and systems that create, acquire, organise, store, distribute, and use information", which enhances the efficient and effective access, process, and use of information by people and organisations. This will result in improvement of both people and organisations in terms of better task completion and competitive and strategic operations respectively (Detlor 2010). The aim of IM is to provide the right information to the right person in the right place at the right time to support the processes efficiently (Robertson 2005; Hicks et al 2006). It is widely believed that IM is critical for projects' success as it ensures that the information value is identified and achieved to its complete level (Hicks et al 2006). However, there are many challenges within the IM that need to be addressed in order to improve the overall projects efficiency (Hicks et al 2006). Table 2 addresses the identified design challenges under four categories related to IM.

Table 2- Information Management Challenges

\begin{tabular}{|c|}
\hline 3.2 Information Management Challenges \\
\hline $\begin{array}{l}\text { A number of information management challenges have been identified in the literature, which are summarised into four main } \\
\text { categories: systems or tools, information, people, and policy and strategy. Managing all types of documented information } \\
\text { throughout the information management lifecycle needs an integration of policies, systems, information, and people. The relation } \\
\text { between these challenges and construction design problems are also summarised in table } 3 \text { and } 4 \text {. }\end{array}$ \\
\hline 3.2.1 Systems or Tools \\
\hline $\begin{array}{l}\text { Developed information management strategies are merged with systems and operations for a set of pre-defined or on-going actions } \\
\text { (Hicks et al 2006). Nevertheless, most of the elements are not in line with organisations and systems (Duhan Levy and Powell } \\
\text { 2001). Therefore, many issues related to inappropriate management systems will result in poor information management along } \\
\text { with design problems. }\end{array}$ \\
\hline 3.2.2 Information \\
\hline $\begin{array}{l}\text { Recently with the increased amount of information generated and being available in the design process it is crucial to deal with a } \\
\text { large amount of information (Leite et al 2016). The increased potential of creating and accessing information with various } \\
\text { technological devices has maximised the capacity of generating information (Hicks et al 2006). Increased level of information not } \\
\text { only effects managing the excess amount of information (Edmunds and Morris 2000), but also effects managing the possible ways } \\
\text { for different levels of information. Moreover, construction companies require various types of rich information for managing } \\
\text { project life cycle activities in the design phase (Pahl and Beitz 2013). Hence, increased level of information has resulted in } \\
\text { creating many issues. }\end{array}$ \\
\hline
\end{tabular}

3.2.3 People

To accomplish client's requirements, project participants work through a strategic process to achieve predetermined set of goals during the design process. The process consists of developing and sharing of relevant information. It has been identified that due to complexity of these information, effective information management is a key component in successful project delivery. Many organisations recognised that collaboration and coordination improvement among project stakeholders is a crucial need in effective information management (Peansupap and Walker 2005), Organisations should consider people with relevant skills and performance for a better information management through a process of collecting, organising and maintaining information to overcome related issues (Marchand Kettinger and Rollins, 2000).

\subsubsection{Policy and strategy}

According to Karimi and Konsynski (1991) "A global information management strategy is needed as a result of (1) industry globalisation: the growing globalisation trend in many industries and the associated reliance on information technologies for coordination and operation, and (2) national competitive posture: the aggregation of separate domestic strategies in individual countries that may contend with coordination." Global strategies are linked with the involvement of coordination which includes the management of exchange sets; such as information, goods, expertise, technology, and finances (Powell 1987).

The four identified IM challenges mentioned above would result in major construction design problems as explained in Tables 3 and 4. The IM challenges are listed in Tables 3 and 4 along with their relation to the construction design problems which are categorised into six types (shown as a-f items). For example, problems associated with the information aspect, such as lack of information availability, will result in unbalanced sharing of resources (item c in Table 3). 
Table 3- Construction design problems related to IM Challenges

\begin{tabular}{|c|c|c|}
\hline Categories and Description & Construction design problems & Information Management challenges \\
\hline $\begin{array}{l}\text { Developed information } \\
\text { management strategies } \\
\text { are merged with systems }\end{array}$ & $\begin{array}{l}\text { a) Lack of communication } \\
\text { and coordination }\end{array}$ & $\begin{array}{l}\text { Large number of disparate information management systems, } \\
\text { Little integration or coordination between information systems, } \\
\text { Information exchange, Manual systems and data entry, } \\
\text { Implementation and customisation of information systems, } \\
\text { Paper based systems. (Robertson, 2005; Hicks et al, 2006). }\end{array}$ \\
\hline $\begin{array}{l}\text { and operations for a set of } \\
\text { pre-defined or on-going } \\
\text { actions (Hicks et al., 2006). } \\
\text { Nevertheless, most of the }\end{array}$ & b) Insufficient documentation & $\begin{array}{l}\text { Range of legacy systems requiring upgrading or replacement, } \\
\text { Information exchange, Manual systems and data entry, Paper } \\
\text { based systems. (Robertson, 2005; Hicks et al, 2006). }\end{array}$ \\
\hline $\begin{array}{l}\text { Nevertheless, most of the } \\
\text { elements are not in line with } \\
\text { organizations and systems } \\
\text { (Duhan, Levy, \& Powell, } \\
\text { 2001). }\end{array}$ & e) Unreliable decision making. & $\begin{array}{l}\text { Direct competition between information management } \\
\text { systems, No clear strategic direction for the overall technology } \\
\text { environment, Limited and patchy adoption of existing } \\
\text { information, systems by staff, Manual systems and data } \\
\text { entry, Functionality of information systems, Paper based } \\
\text { systems. (Robertson, 2005; Hicks et al, 2006). }\end{array}$ \\
\hline $\begin{array}{l}\text { Information } \\
\text { Increased level of } \\
\text { information not only } \\
\text { affects in managing and } \\
\text { excess of information } \\
\text { (Edmunds \& Morris, } \\
2000 \text { ), but also to } \\
\text { establish managing } \\
\text { ways for different levels } \\
\text { of information. }\end{array}$ & $\begin{array}{l}\text { a) Lack of communication and } \\
\text { coordination } \\
\text { b) Insufficient documentation } \\
\text { c) Unbalanced sharing of resources } \\
\text { d) Poor or missing input information } \\
\text { e) Unreliable decision making } \\
\text { f) Design changes }\end{array}$ & $\begin{array}{l}\text { Little integration or coordination between information } \\
\text { systems, Large number of diverse business needs and issues to } \\
\text { be addressed, Limited resources for deploying, managing or } \\
\text { improving information systems, Large number of diverse } \\
\text { business needs and issues to be addressed, Lack of clarity } \\
\text { around broader organisational strategies and directions, } \\
\text { Difficulties in changing working practices and processes of staff, } \\
\text { Information exchange, Functionality of information } \\
\text { systems, Information availability and accessibility, Information } \\
\text { identification, location and organisation, Paper based systems. } \\
\text { (Robertson, 2005; Hicks et al, 2006). }\end{array}$ \\
\hline
\end{tabular}

Table 4- Construction design problems related to IM Challenges (Continued)

\begin{tabular}{|c|c|c|}
\hline Categories and Description & Construction design problem & Information Management challenges \\
\hline $\begin{array}{c}\text { People } \\
\text { Many A \& E } \\
\text { organizations identified }\end{array}$ & $\begin{array}{l}\text { a) Lack of } \\
\text { communication }\end{array}$ & $\begin{array}{l}\text { Little integration or coordination between information systems, Large number of diverse } \\
\text { business needs and issues to be addressed, Manual systems and data entry, Information } \\
\text { flow from customers and sales, Information availability and accessibility, Implementation } \\
\text { and customisation of information systems, Information completeness and aceuracy, Paper } \\
\text { based systems. (Robertson, 2005; Hicks et al, 2006). }\end{array}$ \\
\hline $\begin{array}{l}\text { that improving } \\
\text { collaboration } \\
\text { and coordination }\end{array}$ & $\begin{array}{l}\text { b) Insufficient } \\
\text { documentation }\end{array}$ & $\begin{array}{l}\text { Large number of diverse business needs and issues to be addressed, Information availability } \\
\text { and accessibility, Information completeness and accuracy, Information duplication, Paper } \\
\text { based systems. (Robertson, 2005; Hicks et al, 2006). }\end{array}$ \\
\hline $\begin{array}{l}\text { among project } \\
\text { stakeholders is } \\
\text { a crucial need in } \\
\text { effective information }\end{array}$ & $\begin{array}{l}\text { c) Unbalanced sharing } \\
\text { of resources }\end{array}$ & $\begin{array}{l}\text { Little recognition and support of information management by senior } \\
\text { management, Difficulties in changing working practices and processes of staff, Manual } \\
\text { systems and data entry, Information flow from customers and sales, Information } \\
\text { completeness and accuracy, information duplication. (Robertson, 2005; Hicks et al, 2006). }\end{array}$ \\
\hline $\begin{array}{l}\text { management } \\
\text { (Peansupap and } \\
\text { Walker 2005). }\end{array}$ & $\begin{array}{l}\text { e) Unreliable decision } \\
\text { making }\end{array}$ & $\begin{array}{l}\text { No clear strategic direction for the overall technology environment, Limited and patchy } \\
\text { adoption of existing information systems by staff, Large number of diverse business needs } \\
\text { and issues to be addressed, Internal politics impacting on the ability to coordinate activities } \\
\text { enterprise-wide Information completeness and accuracy, Information duplication. } \\
\text { (Robertson, 2005; Hicks et al, 2006). }\end{array}$ \\
\hline $\begin{array}{l}\text { Policy and Strategy } \\
\text { According to Karimi and } \\
\text { Konsynski (1991) “A global } \\
\text { information management }\end{array}$ & $\begin{array}{l}\text { a) Lack of } \\
\text { communication }\end{array}$ & $\begin{array}{l}\text { Lack of clarity around broader organisational strategies and directions, Information flow } \\
\text { from customers and sales, Information availability and accessibility, Information } \\
\text { identification, location and organisation. (Robertson, 2005; Hicks et al, 2006). }\end{array}$ \\
\hline $\begin{array}{l}\text { strategy is needed as a } \\
\text { result of (I) industry } \\
\text { globalization: the growing }\end{array}$ & $\begin{array}{l}\text { b) Insufficient } \\
\text { documentation }\end{array}$ & $\begin{array}{l}\text { Lack of enterprise-wide definitions for information types and values (no corporate wide } \\
\text { taxonomy), Information availability and accessibility, Information identification, location } \\
\text { and organisation. (Robertson, 2005; Hicks et al, 2006). }\end{array}$ \\
\hline $\begin{array}{l}\text { globalization trend in many } \\
\text { industries and the } \\
\text { associated reliance on } \\
\text { information technologies, } \\
\text { and (2) national }\end{array}$ & $\begin{array}{l}\text { c) Unbalanced sharing } \\
\text { of resources }\end{array}$ & $\begin{array}{l}\text { Little recognition and support of information management by senior } \\
\text { management, Limited resources for deploying, managing or improving } \\
\text { information systems, Difficulties in changing working practices and processes of } \\
\text { staff, Information flow from customers and sales. (Robertson, 2005; Hicks et al, 2006). }\end{array}$ \\
\hline $\begin{array}{l}\text { and (2) national } \\
\text { competitive posture: the } \\
\text { aggregation of separate } \\
\text { domestic strategies in } \\
\text { individual countries." }\end{array}$ & $\begin{array}{l}\text { e) Unreliable decision } \\
\text { making }\end{array}$ & $\begin{array}{l}\text { No clear strategic direction for the overall technology environment, Large number of diverse } \\
\text { business needs and issues to be addressed, Lack of clarity around broader organisational } \\
\text { strategies and directions, Internal politics impacting on the ability to coordinate activities } \\
\text { enterprise-wide, Functionality of information systems. (Robertson, 2005; Hicks et al, 2006). }\end{array}$ \\
\hline
\end{tabular}

\section{INTERACTION OF BIM AND LEAN TO REDUCE DESIGN PROBLEMS ASSOCIATED WITH INFORMATION MANAGEMENT}

BIM has been widely recognised as a platform which is related to Information Management (IM), and has been defined as "not just a technology change, but also a process change" that enables "a building to be represented by intelligent objects that carry detailed information" (Eastman et al 2011). BIM has various beneficial functionalities that would improve information management and accordingly the design process. Four main 
BIM functionalities that have the most interaction with Lean principles were identified by Mollasalehi et al. (2015) which can also be linked to IM. These are discussed in the following section.

According to Koskela et al (2002), "lean is a way to design production systems to minimise waste of material, time, and effort in order to generate the maximum possible amount of value". There are many different Lean principles that are beneficial to the overall project process including information management process. Though, five key lean principles that were identified to have the most interaction with BIM functionalities which are linked to IM are: Reduce variability, reduce cycle time, increase flexibility, use visual management, and verify and validate (Sacks et al 2010).

There is a strong synergy between BIM and Lean (Sacks et al 2010). Therefore, the integration of these two approaches would enhance IM through different beneficial features that they provide as shown in Table 7. Table 7 demonstrates the benefits of integrating BIM and Lean approaches to improve information management in terms of reducing construction design problems that are related to IM challenges.

\subsection{Discussion Based on Table 7}

Table 7 shows four different types of linkages between IM challenges (numbers 1-4) in line with integrated BIM and Lean, and construction design problems (items a-f). Different construction design problems have been highlighted according to the previous discussion in tables 3 and 4 . For example, there are only three identified relevant construction design problems (items a, b, and e), as previously discussed in table 3, which have either direct or indirect interaction with BIM and Lean in terms of IM process improvement. This has been discussed in details in Table 5 and 6 below.

Table 5- Discussion based on Table 7

\begin{tabular}{|c|}
\hline Visualisation \\
\hline 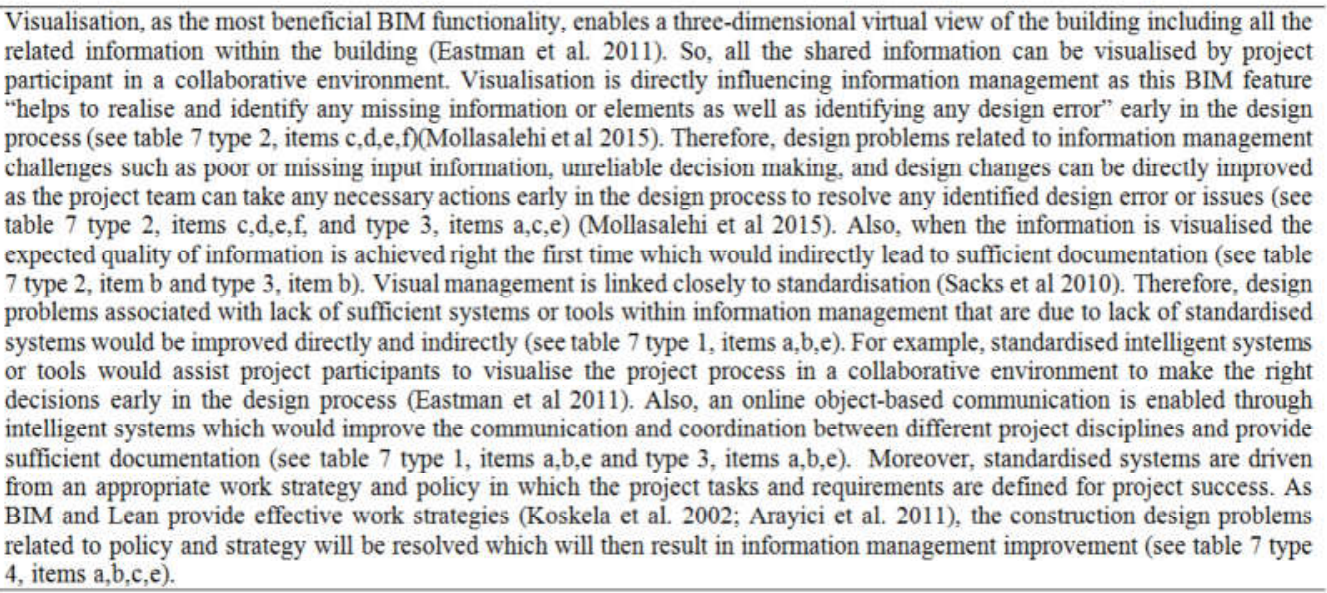 \\
\hline
\end{tabular}

Clash detection

Clash detection enables identifying and reporting of any interference and clashes between systems and objects (see table 7 type 1 , items a,b,e). These improved systems and strategies allow people to take more reliable decision making through improved communication and coordination among project stakeholders (see table 7 type 1, items a,b,e and type 3, items a,b,c,e)(Arayici et al 2011). Similarly, Eastman et al. (2011) stated that "Automatic detection of conflicts is an excellent method for identifying design errors, where objects either occupy the same space (a hard clash) or are too close (a soft clash)". Therefore, clash detection improves the richness of the information exchange reducing poor and missing input information to avoid future design changes and unreliable decision making (see table 7 type 2, items a-f). Likewise, human errors could be identified through clash detection, enhanced to improve balanced sharing of resources among project stakeholders (see table 7 type $3 \mathrm{a}, \mathrm{b}, \mathrm{c}, \mathrm{e}$ ). 
Table 6- Discussion based on Table 7 (continued)

\begin{tabular}{|c|}
\hline Collaboration \\
\hline 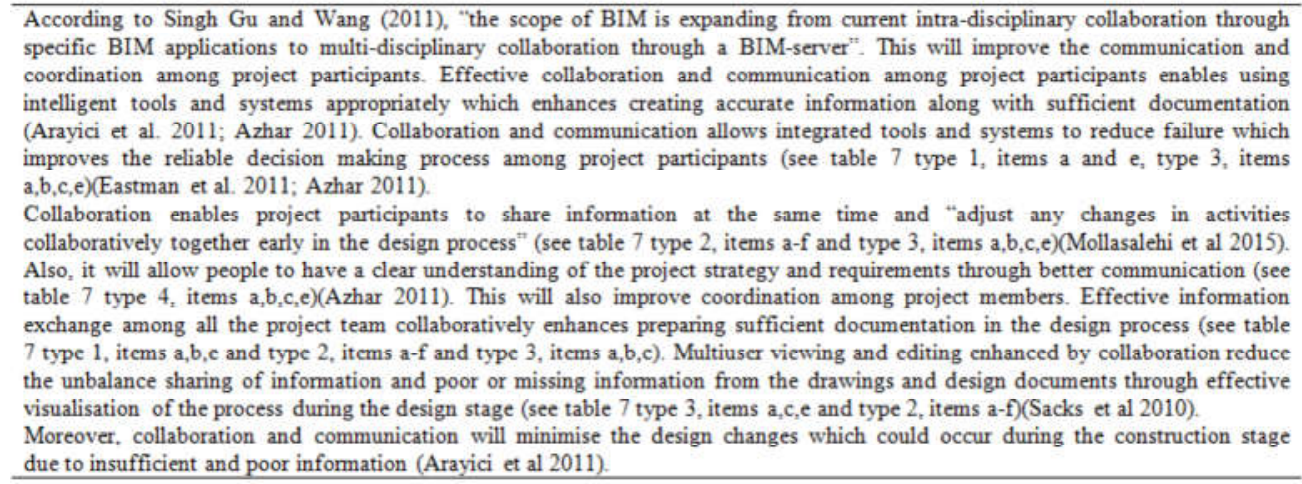 \\
\hline 4D scheduling and construction sequence planning \\
\hline 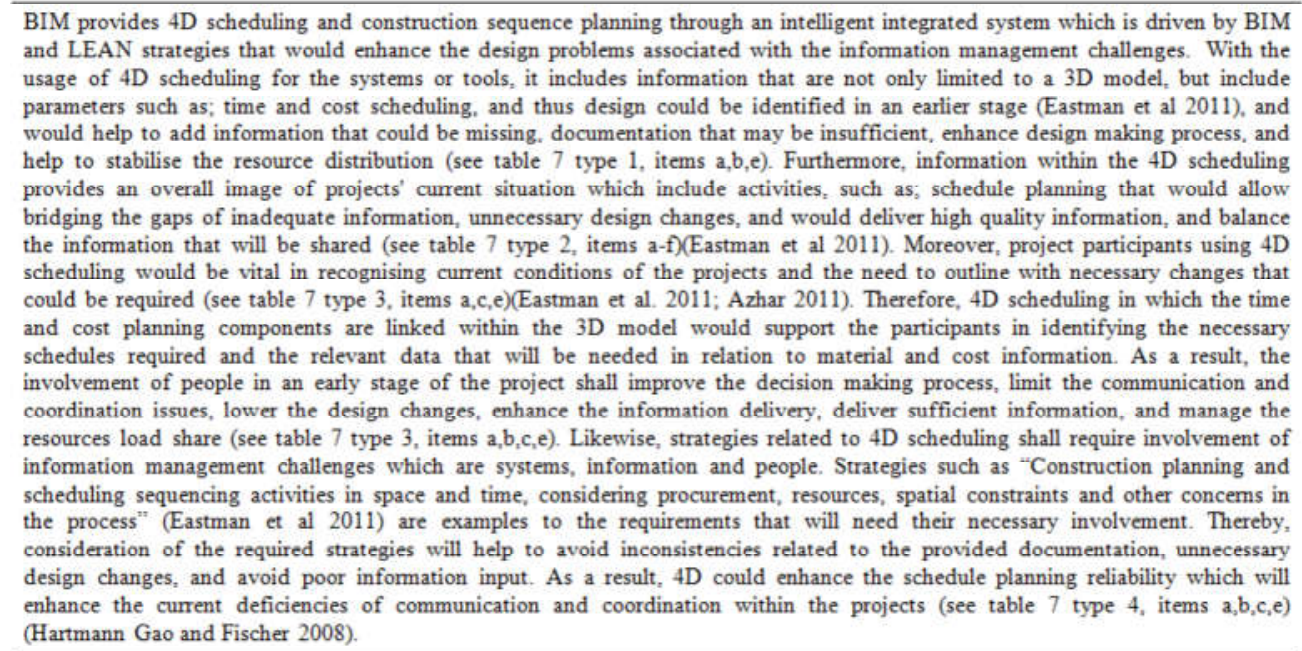 \\
\hline
\end{tabular}

Table 7- Interaction of BIM/Lean to Enhance Information Management

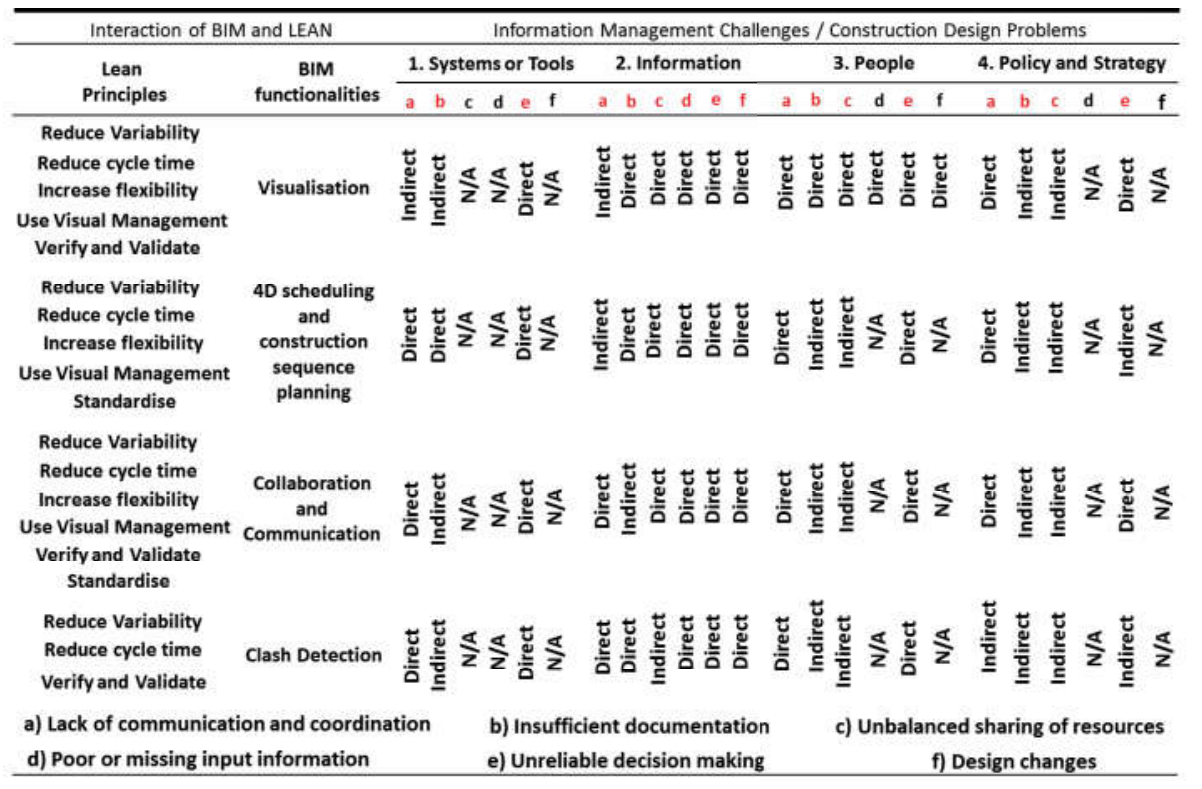


Sajedeh Mollasalehi, Anushka Rathnayake, Ahmed Adel Aboumoemen, Jason Underwood, Andrew Fleming, Udayangani Kulatunga and Paul Coates

\section{CONCLUSION}

It is widely believed that many of the problems faced by the construction industry are related to the design process. Some of the key challenges within the construction design have been highlighted in this paper such as lack of communication and coordination, poor or missing input information, design changes, and unreliable decision making. These problems will result in many challenges within the information management (IM) which would make the IM insufficient. This paper identified some of the key IM challenges within the design process which have been summarised into four main categories of systems or tools, information, people, and policy and strategy. These challenges have been linked to the construction design problems and it is believed by the authors that by improving those, the IM will be accordingly improved. BIM and Lean as two innovative and technological processes are believed to enhance IM. It is believed that the integration of BIM functionalities (such as visualisation and collaboration) with Lean principles (such as reduce variability, increase flexibility and use visual management) enable better IM improvement during the design process. Table 7 has been provided to show the relation between the integrated BIM and Lean and IM improvement. The interaction of BIM and Lean column in the table has been adopted from 'Interaction Matrix of Lean Principles and BIM Functionalities' (Sacks et al 2010). From the discussion of the proposed table (chapter 4.1) it can be concluded that the interaction of BIM and Lean would benefit IM in terms of reducing construction design problems that are associated with the IM problems. As this paper is based on reviewing the literature, authors would like to recommend future practical work based on the proposed table to gain more insight into this area of research.

\section{REFERENCES}

Arayici, Y., Coates, P., Koskela, L., Kagioglou, M., Usher, C., \& O'Reilly, K. (2011). BIM adoption and implementation for architectural practices. Structural survey, 29(1), pp. 7-25. doi: 10.1108/02630801111118377(7), 7-25

Austin, S., Baldwin, A., \& Newton, A. (1994). Manipulating the flow of design information to improve the programming of building design. Construction management and economics,12(5), pp. 445-455. doi: 10.1080/01446199400000054 (445), 445-455

Azhar, S. (2011). Building information modeling (BIM): Trends, benefits, risks, and challenges for the AEC industry. Leadership and Management in Engineering, 11(3), pp. 241-252. doi: 10.1061/(ASCE)LM.1943-5630.0000127(241), 241-252

Baldwin, A. N., Austin, S. A., Hassan, T. M., \& Thorpe, A. (2010). Modelling information flow during the conceptual and schematic stages of building design. Construction Management \& Economics, 17(2), pp. 155-167. doi:1080/014461999371655(155), 155167.

Detlor, B. (2010). Information management. International Journal of Information Management, 30 (2), pp. 103-108.

Duhan, S., Levy, M., \& Powell, P. (2001). Information systems strategies in knowledgebased SMEs: the role of core competencies. European Journal of Information Systems, 10(1), pp. 25-40. doi:10.1057/palgrave.ejis.3000379 (25), 25-40.

Eastman, C., Teicholz, P., Sacks, R. and Liston, K. (2011). BIM handbook: A guide to building information modeling for owners, managers, designers, engineers, and contractors (2nd ed.). Hoboken, N.J.: John Wiley \& Sons. 
Edmunds, A., \& Morris, A. (2000). The problem of information overload in business organisations: a review of the literature. International journal of information management, 20(1), pp. 17-28. doi: 10.1016/S0268-4012(99)00051-1 (17), 17-28.

Formoso, C. T., Tzotzopoulos, P., Jobim, M. S., \& Liedtke, R. (1998). Developing a protocol for managing the design process in the building industry. In 6th Annual Conference of the International Group for Lean Construction, Guaruja, SP.

Freire, J., \& Alarcon, L. F. (2002). Achieving lean design process: improvement methodology. Journal of Construction Engineering and management, 128(3), pp. 248256. doi: 10.1061/(ASCE)0733-9364(2002)128:3(248), 248-256.

Hartmann, T., Gao, J., \& Fischer, M. (2008). Areas of Application for 3D and 4D Models on Construction Projects. Journal of Construction Engineering and Management, 143(10),pp.776-785. 10.1061/0733-9364(2008)134:10(776), 776-785.

Hicks, J., Culley, J., \& McMahon, A. (2006). A study of issues relating to information management across engineering SMEs. International Journal of Information Management,26(4),pp.267-289.doi: 10.1016/j.ijinfomgt.2006.03.006 (267), 267-289

Karimi, J., \& Konsynski, B. R. (1991). Globalization and information management strategies. Journal of management information systems, 7(4), pp. 7-26. doi: 10.1080/07421222.1991.11517901(7), 7-26

Koskela, L., Howell, G., Ballard, G., \& Tommelein, I. (2002). The foundations of lean construction. Design and Construction Building in Value. Oxford, UK.

Leite, F., Cho, Y., Behzadan, A. H., Lee, S., Choe, S., Fang, Y., \& Hwang, S. (2016). Visualization, Information Modeling, and Simulation: Grand Challenges in the Construction Industry. Journal of Computing in Civil Engineering, 30(6). doi: 10.1061/CP.1943-5487.0000604.

Marchand, A., Kettinger, J., \& Rollins, D. (2000). Information orientation: people, technology and the bottom line. MIT Sloan Management Review,41(4),pp. 69.

Mollasalehi, S., Fleming, A., Talebi, A. \& Underwood, J., (2016). Development of an Experimental Waste Framework Based on Bim/Lean Concept in Construction Design In: 24th Annual Conference of the IGLC Boston, USA, 20-22 Jul 2016.

Ningappa, N. (2011). Use of lean and Building Information Modeling (BIM) in the construction process; does BIM make it leaner?. (Unpublished MSc thesis).

Pahl, G., \& Beitz, W. (2013). Engineering design: a systematic approach. Springer Science $\&$ Business Media.

Peansupap, V., \& Walker, D. H. (2005). Factors enabling information and communication technology diffusion and actual implementation in construction organisations. Electronic Journal of Information Technology in Construction, 10(14), pp. 193-218.

Powell, W. (1987). Hybrid organizational arrangements: new form or transitional development?.California management review, 30(1), pp. 67-87. doi: 10.2307/41165267(67), 67-87.

Robertson, J. (2005). 10 principles of effective information management. KM Column.

Sacks, R., Koskela, L., Dave, B. A., \& Owen, R. (2010). Interaction of lean and building information modeling in construction. Journal of construction engineering and management, 136(9), pp. 968-980. doi: 10.1061/(ASCE)CO.1943-7862.0000203 (968), 968-980

Singh, V., Gu, N., \& Wang, X. (2011). A theoretical framework of a BIM-based multidisciplinary collaboration platform. Automation in construction, 20(2), pp. 134-144. doi: 10.1016/j.autcon.2010.09.011 (134), 134-144 